\title{
Upazila Parishad in Bangladesh: Roles and Functions of Elected Representatives and Bureaucrats
}

Commonwealth Journal of Local Governance

\author{
Muhammad Sayadur Rahman \\ Department of Public Administration \\ Jahangirnagar University \\ Bangledesh
}

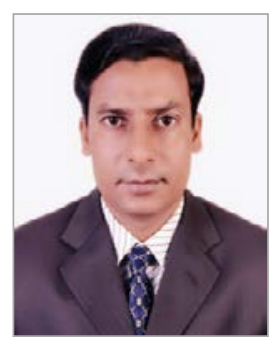

\begin{abstract}
This study explores whether democratic Upazila Parishads in Bangladesh have become more responsive to those who elected them and whether people's expectations about their elected representatives and their functions to their elected have changed. The study carried out in eight Upazilas from seven Divisions in Bangladesh. The study has found that Upazila Parishads in Bangladesh with democratically elected representatives have largely failed to enhance their rapport with people. The recently implemented mandatory advisory role for the members of the parliament (MPs) has complicated the role of the local government and the interference by MPs in local government affairs has weakened the independence of local government. The findings of this study reveal that awareness is low, and that only 30\% of respondents were concerned about the roles and functions of the Upazila Parishad. The data reveals that though the local citizens think that they are knowledgeable about the roles and functions of elected representatives and bureaucrats in reality many remain unaware of the roles and functions.
\end{abstract}

Key Words: Bangladesh, Local Government, Role, Elected Representatives, Bureaucrats, Perceptions, Upazila Parishad.

\subsection{The problem}

Bangladesh has a relatively a long experience and familiarity with local government and administration, but an appropriate structure of local government is yet to be established. Various attempts have been made to restructure the local government before independence, but local government in Bangladesh is typically dominated by central bureaucrats and politicians those who lead from the centre (Rahman, 2010; Ahmed, 2009). The issue of strengthening local governments was a priority during the two-year long Caretaker Government (CG) of Dr. Fakhruddin Ahmed from 2007 to 2009, and under pressure from the civil society the Local Government (Upazila Parishad) Ordinance was passed in 2008 setting up the Upazila Parishad as a free and independent local government organization directly elected by the people. 
The administrative structure of Bangladesh includes seven Divisions. Within these lie urban authorities are single tiered and rural local government which has three tiers: 64 Districts, divided into around 500 Upazila Parishad, subdivided again into around 4,500 and Union Parishad. Upazila Parishads have an average population of around 250,000 people (CLGF, 2012). Each Upazila has an elected Chairman, Vice-Chairman and Members; the membership must include a Woman ViceChairman and reserved seats for women.

Under the 2008 Upazila Ordinance, elections were held on January 22, 2009 in most of the 482 Upazilas of the country, within less than a month of the ninth parliamentary election, to elect a Chairman, Vice Chairman and Members of each Upazila Parishad. Once the newly elected Upazila Parishad were established, the old issue of power sharing between local MPs, bureaucrats and Upazila Chairmen once again surfaced. The MPs were fearful of losing control over the Upazila activities and forced the Caretaker Government to amend the Upazila Parishad Ordinance making MPs as advisers in the Upazila affairs. On 7 April 2009, Parliament passed the Upazila Parishad (Reintroduction of the Repealed Act Amendment) Act 2009, restoring powers of MPs over the councils and making the elected Chairmen virtually powerless. As a result, In November 8, 2009 the High Court (in response to the writ of a Chairman) asked the government: why the MPs should be retained as advisers to the Upazila Parishad, a local government body; why the appointment the MPs as advisers to Upazila Parishad should not be declared illegal, and why the retention of Upazila Nirbahi Officers as presidents of standing committees should not be declared illegal.

The role of Upazila Nirbahi Officer (UNO) was supposed to be limited to secretarial functions of the Upazila Parisad, supported by the new posts of Upazila Chairman, and Vice Chairman (the latter reserved for women, to ensure women's participations in the Upazila Parisad, although their powers are limited). There are also various conflicts between politicians and bureaucrats in different local government agencies over policy implementation, and resources. Relations between public representatives and officials at the Upazila level are strained because of an unclear allocation of authority, and people suffer as a result poor public services (The Daily Star, April 24, 2010). Moreover, recently the government approved a proposal for an Upazila Parishad Bill to make the UNO the Parishad's principal executive officer vested with financial powers (The Daily Star, April 20, 2010). Now, even three years after being elected, the Upazila Chairmen and Vice-Chairmen are unclear of their roles in relation to UNOs and local MPs. 
The Upazila Chairmen have been protesting against the Act since it was passed. According to the new law, recommended by the Parliamentary Standing Committee on Local Government, elected Chairmen will be mainly in charge of planning and monitoring development programmes, which is likely to reduce the role of MPs in local governmen, The views and perceptions of local citizens are imporant in this regard. The core issue is whether local government will merely implement national programmes at the local level, or will be a self-ruled local administration, as defined in the amended Constitution, under Articles 9, 59, and 60 (Siddiqui, 2005). In this present pro-democracy climate, it is argued there that local government should be strengthened. Now the questions are; what is the present condition of Upazila? What should be the role of elected representatives in the local government and what are the views and perceptions of local people about the role of their elected representatives? This study aims to find out the answer of these questions, with an empirical perspective of local government especially in the case of Upazila administration as a significant tier of local government in Bangladesh.

\subsection{Importance and objectives}

The Upazila Parishads are midway between local and central government, and are a very important tier of political-administrative nexus. More importantly, to carry out the government programmes, Upazila provide a bridge between local and national government. Recently Upazila administration has been brought under democratic control headed by directly elected representatives (Ahmed et al 2011). Elected representatives and bureaucrats are an integral part of the governance and policy process of the Upazila administration. So, the effective function of Upazila depends on the mode of interaction between the sets of actors, elected politicians and bureaucrats. Three core governing actors (MP, UPC and UNO) are directly and indirectly involved in the Upazila Parishad. The roles and functions of these actors in Upazila Parishad is a hot topic of discussion. A clear understanding of roles and functions of the core actors can be considered as a first major step towards initiating proper operation of the Upazila Parishad.

In a post-colonial structure government, local government is a development partner of central government, and in Bangladesh it is very difficult to confine the role of MPs to parliament. In the past, the role of the MPs in local government was not defined and there was no provision to link MPs with the local government system (Siddiqui, 2005). Moreover, the role of local government functionaries and lawmakers has never been clearly demarcated in Bangladesh, and the distinction of roles between the elected local government functionaries and members of parliament has blurred. Currently, lawmakers are advisers to district and Upazila councils, the two crucial tiers of the country's three-tier local government system. According to relevant laws, legislators are supposed to 
advise but in reality they dictate the affairs of local government bodies and directly engage in executive functions at the grassroots (The Daily New Age, November 14, 2007). Empowering lawmakers to interfere with the administration of local government bodies goes against the constitutional provision of Bangladesh. As a result, local government has been facing a triangle of conflict between the MPs, local elected chairmen and bureaucrats over roles and power sharing.

The central questions are thus: What should be the role of elected representatives and bureaucrats in the local government? What are the views and perceptions of the grassroots communities? This study aims to provide an empirical focus or overview of these questions in order to:

1. Explore the roles and functions of elected representatives and bureaucrats;

2. Identify the level of awareness of local communities;

3. Identify the views and perceptions of grassroots communities on the role of elected representatives in local government.

\subsection{Methodology}

The study draws on case studies of eight Upazila administrations, drawing on two sources of data: primary and secondary. Primary data was collected from the eight Upazilas in seven Divisions using structured and unstructured questions (close-ended and open-ended). Respondents were selected from six categories: the elected Chairman, Vice Chairmen, Members, the appointed Upazila Nibahi Officer (UNO), other government officials, and people from the local community. Secondary data and information was collected from published books, journals, newspapers, articles and the internet. The sample included purposive categories of the respondents; local members, local officials and residents, resulting in 160 interviews from the eight Upazilas including 20 from each Upazila. The Chairmen of the selected Upazilas and UNOs were also interviewed; the Women Vice-Chairmen could not be reached during the data collection period. Table 1.1 shows the distribution of the sample. The eight Upazilas are suburban and semi-urban in character. The socio-economic conditions of the Upazilas are similar but the political composition of the Upazilas is varied. 
Table 1.1: Sample Distribution

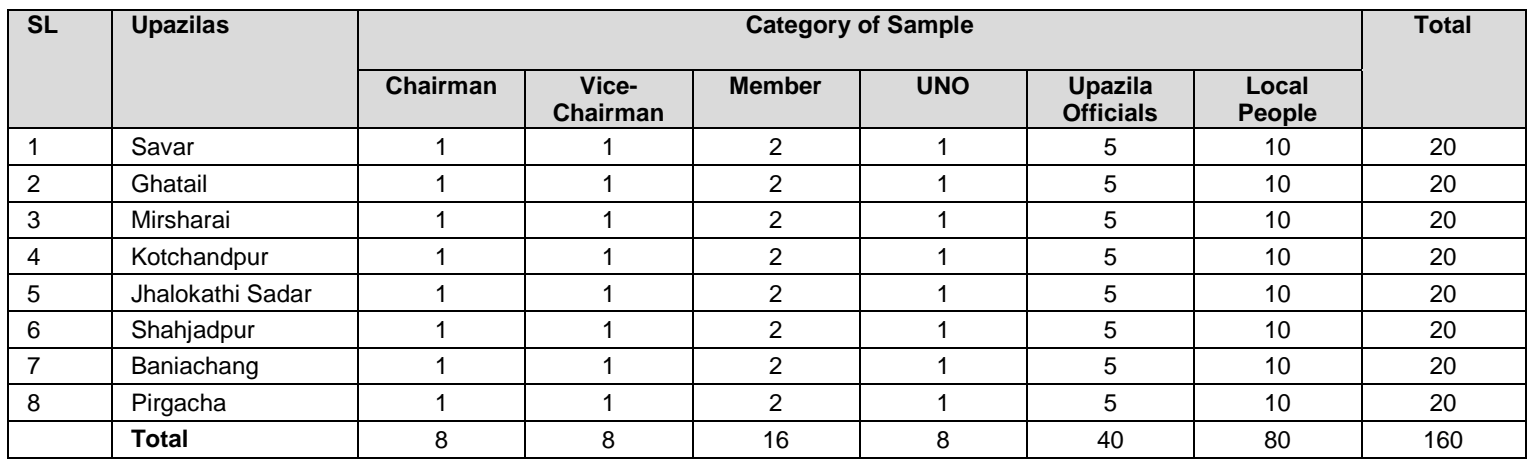

\subsection{Limitations}

The main limitations of the study can be discussed as follows:

- Existing literature on the role of public representatives in the local government is limited, although there is much literature on the politics-bureaucracy relationship at national government level;

- There were some problems in data collection,as Union Parishad elections were due and local politicians and bureaucrats faced some tensions over their power and functions, which meant they were cautious about providing data;

- Respondents did not always provide comprehensive or consistent answers, making. data collection difficult;

- Ideally, the study should have included three different questionnaire for local elected representatives, local government officials, and the public, but time and financial constraint made this impossible;

- Finally the sample size was limited because of time constrains, which makes it difficult to make a generalization on the whole system of local government and the views and perceptions of the local citizens.

\subsection{Theoretical and conceptual framework}

In this study the main and dominant concept is 'role'. Role performance and decision-making is a very important part of the administration as defined in the literature. As Davis (1948) notes, 'how an individual actually performs in a given position, as distinct from how he is supposed to perform, we call a role'. The role is the manner in which a person actually carries out the decisions in keeping his position. It is the dynamic aspect of status or office and always influenced by factors other than the stipulation of the position itself. Role can be identified in two ways, expected role and performed role. Aberbach et al (1981) provided more comprehensive account of the role of politicians and 
bureaucrats. They argue that politicians and bureaucrats each play nine types of roles, that of: technician, advocate, trustee, legalist, broker, partisan, facilitator, policymaker, and ombudsman. From the literature review (Stilborn, 2012; Arblaster, 2002; Lilleker and Jackson, 2009; Rush, 2001; Pickles, 1971; Wahlke et al 1962; Norton and Wood, 1990; Norton, 1994), four main roles of Public Representatives were identified: delegate, trustee, partisan and constituency service. However, to avoid the divergence of defining role in this study, the role has been operationalized as 'the expected and performed duties and functions of the elected representatives and bureaucrats which are granted by the law'.

Figure 1: Roles and Functions of Elective Representatives and Bureaucrats in Theoretical Perspective

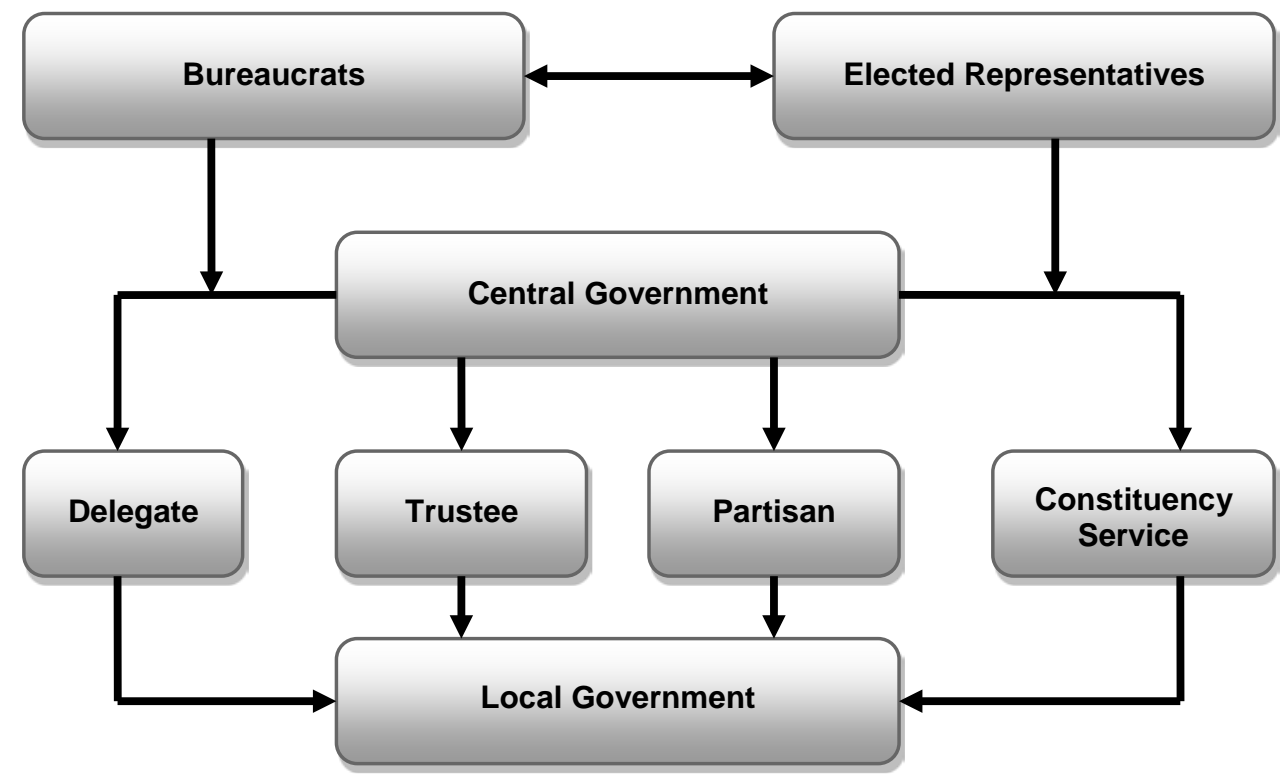

\subsection{Roles and responsibilities of elected representatives in Bangladesh}

In Bangladesh, there are two types of elected representatives, one who led the local government namely Chairmen and other who led central government namely Members of Parliament. They are elected by groups of citizens irrespective of the kind of electoral system under which they are chosen. (GOB, 2001).

According to the Constitution of the People's Republic of Bangladesh, 'there shall be a Parliament for Bangladesh (to be known as the House of the Nation) in which subject to the provisions of this Constitution, shall be vested the legislative powers of the Republic' (Article 65 (1). According to Article 65(1), MPs are vested with legislative powers of the Republic and so their supreme obligation is to formulate, modify various legislation with a view to administering the country for the people, as Article 7(1) confirms that all powers in the Republic belong to the people. 
According to Article 59(1) of the Constitution, local government bodies in every administrative unit are the major actors in local development work. Article 60 of the Constitution clearly defines that, “.... Parliament shall, by law, confer powers on the local government bodies, including power to impose taxes for local purposes, to prepare their budgets and to maintain funds”. So Parliament is constitutionally bound to provide the local government bodies with full autonomy. Hopefully, instead of involving the MPs in local development works, Parliament will facilitate the local governments to become effective and efficient in line with the constitution, emphasizing the 'constituency service' role of an MP.

For this, Government may allocate offices for the MPs in their constituencies so that they can keep in close touch with constituents to assess their opinions on proposed policy and laws. MPs should monitor local government activities from a distance to ensure that they follow the approved Parliamentary policies, for which the Constitution gives them a special responsibility: eg: Articles 78(1), 78(2), 78(3), 78(4) render the immunity of MPs in their speeches to any parliamentary session. Unfortunately, in the past, many MPs misused this privilege and turned the Parliament into an unprofessional and unethical discussion forum. To make the Parliament effective, Article 76 provides for appointing Standing Committees of Parliament on different issues of public importance. These highly empowered committees should examine draft bills and other legislative proposals, review the enforcement of laws and monitor the activities of the concerned ministries.

Members are nonetheless immediately confronted by a variety of responsibilities, and their roles are often summarized as representative, legislator and scrutinizer of government. The first refers to the fact that MPs have been elected to parliament as representatives of their electorates. The second reflects what most people see as the central responsibility of an MP, to pass or amend legislation. The third covers the scrutiny or oversight that parliamentarians exercise over the workings of the executive and the implementation of legislation. This function also extends to the support or criticism of proposals placed before parliament by government and in the committee systems in the parliamentary government.

\subsection{History and politics of development and decentralization}

After the independence of Bangladesh in 1971, the Awami League-led government in its first year of rule in 1972 made several attempts to replace the traditional local leadership with the party local rank. In 1972, the government abolished the Pakistani Union Council system and formed "Union Panchayats" with government nominated members and also formed "Union Relief Committees" (Khan, 2009). Lawmakers along with local party wings selected members for the two bodies, which 
played a vital role in distributing relief and in reconstruction and rehabilitation (Rahman, 2009). Therefore, legislators had a good opportunity to consolidate their power by picking loyal supporters for the two bodies. The venture thus spoiled the government's image largely because of widespread corruption of relief committees, contributing to Awami League-backed candidates' massive defeat in the 1973 Union council elections.

In 1975, the then Awami League government abolished the elected local government system, declaring a state of emergency, under a single political party the Bangladesh Krishak Sramik Awami League (BAKSAL). A District Governor then headed administration at the district level, and the traditional local government was supplanted by party machinery. Alongside members of the public service and members of BAKSAL, some lawmakers were also appointed as District Governors who were empowered to control all government offices and departments at district level. The system, however, was nullified following the assassination of President, Sheikh Mujibur Rahman, in 1975 and after the military coup. Utilising local government bodies, the military President, Ziaur Rahman, consolidated his power and formed the political party BNP. By the end of 1980, the president introduced a new structure of rural institutions, Swanirvar Gram Sarkar (Self-Reliant village government) in 68,000 Bangladesh villages, marginalising the Union Parishads. MPs took chairmanship of District and Thana (sub-district) level Gram Sarkar coordination committees. The government claimed that Gram Sarkars were formed to ensure people's participation in development; for the first time, politics was localized but people speculated that the president was trying to build a party through Gram Sarkar, but the selection process was criticised because most committees were formed with members of ruling BNP.

Following another military coup in 1982, General HM Ershad became president, abolishing the unpopular Gram Sarkar system to win over local representatives and during the 1980s, and the concept of decentralization started gaining momentum in Bangladesh. In 1982, the formation of Upazila administration was initiated by General Ershad, as a part of the decentralization policy, through the Local Government (Upazila Parishad and Upazila Administration Reorganization) Ordinance, 1982. The emergence of MPs through the third parliamentary election in 1986 triggered conflict between lawmakers and Upazila Parishad Chairmen. Irrespective of party affiliation, MPs were looking forward to share the authority of Upazila, as they did not have formal control over local administration. Finally, Ershad-led government introduced Zilla Parishad Act in 1988 (setting up District governments) that made MPs chairmen of the District Parishads. However, after the fall of military rule the newly democratic government was indifferent to the Upazila Parishad. 
Assuming office in 1991, BNP-led government abolished the Upazila system in 1992, a blunder of Himalayan proportions, and formed Thana Unnayn Samannay Committee at the Upazila level to work as a development body. MPs were made advisers to the bodies in the Upazilas under their respective constituencies. Instead of MPs, the BNP-led government appointed Deputy Commissioners as chairmen of the District Parishad. But lawmakers continued dictating deputy commissioners in running the District Parishads' activities. When after a second election in 1996 the Bangladesh Awami League came to power, they set up a Local Government Commission which submitted its 'Report on Local Government Institutions Strengthening' in May 1997. The Commission has recommended a four-tier local government structure including Gram/Palli (Village) Parishad, Union Parishad, Thana/Upazila Parishad and Zila (District) Parishad. Until now only three tiers of local government, Union Parishad, Upazila Parishad and Zila Parishad are operating in the local government structure of Bangladesh. All these tiers are concerned with rural/regional administration. The two major tiers of urban local governments are City Corporations for six of the largest cities, Dhaka, Chittagong, Rajshahi, Khulna, Barisal and Sylhet and the Pourashava for smaller Municipalities (CLGF, 2012).

The Awami League government took initiatives to give a formal structure to the Upazila Parisad passing the Upazila Act. 1998 (GOB, 1998). This decentralization journey obviously aimed to promote participation of local people through local institution building, developing local leadership and accountable bureaucracies (Rahman, 2010). The 1998 legislation also made MPs advisers to the Upazila Parishads under their respective constituencies. But the government could not make much headway in arranging the elections of Upazila Parishad members because of lack of support from the lawmakers and political conflict. MPs were apprehensive of losing their control and share of the benefits from the development work in their constituency. As a result, the Upazila Act, 1998, did not enable local government to work democratically.

Lastly, the issue of strengthening local governments emerged strongly during the two-year long caretaker government (CG) from 2007-2009, and the caretaker government revived the Upazila system in 2008 through an Ordinance which established the Upazila Parisad as a truly free and independent local government body directly elected by the people, but gave no powers MPs as advisers. Later, it repealed the Upazila Parishad Act as a whole and made a new one, the Local Government (Upazila Parishad) Ordinance 2008.

But assuming power in 2009, the Awami League-led government did not ratify the Upazila Parishad Ordinance in parliament. It reintroduced the repealed Upazila Parishad act of 1998 with provisions for making MPs advisers. Lawmakers from the parliamentary standing committee of the Ministry of 
Local Government, Rural Development and Cooperatives (LGRD), however had recommended that the House also make provisions in the city corporation and municipality laws to make MPs advisers to those bodies. The government, however, did not accept the recommendations. Although MPs are advisers, their interference in the Upazila Parishads' functions made those bodies unable to function fully since the elections in January 2009. Against this backdrop, Upazila Parishad Chairmen, ViceChairmen are preparing campaign to regain freedom of operation for the Upazila Parishad.

An executive officer told reporters that MPs are dictating the district Parishads' activities "In fact, the Upazila executive officers, who are secretaries to the Parishads, are running the Upazila Parishads on the advice of MPs," When the Upazila Parishad gets an allocation of annual development programmes, MPs send a list of projects to implement in their constituencies, he said. "We have nothing to do but implement the projects prescribed by MPs," the Chief Executive Officer said (The Daily Star, 3 October 2010).

\subsection{Survey findings: the respondents}

This part of the study analyses of social background or demographic characteristics such as age, occupation, education and gender of the respondents. Attempts will be made to compare the findings with each other of this study.

Table 3.1: Demographic variables of respondents:

\begin{tabular}{|c|c|c|c|c|c|c|c|c|}
\hline \multirow{3}{*}{$\begin{array}{c}\text { Variables } \\
\text { Age }\end{array}$} & \multicolumn{6}{|c|}{ Category of Sample Respondents } & \multirow{2}{*}{\multicolumn{2}{|c|}{$\begin{array}{c}\text { Total Sample Number } \\
\text { and Percentage }\end{array}$}} \\
\hline & \multirow{2}{*}{$\begin{array}{c}\text { Chairman } \\
\text { Number }\end{array}$} & \multirow{2}{*}{$\begin{array}{c}\text { Vice- } \\
\text { Chairman } \\
\text { Number }\end{array}$} & \multirow{2}{*}{$\begin{array}{l}\text { Member } \\
\text { Number }\end{array}$} & \multirow{2}{*}{$\frac{\text { UNO }}{\text { Number }}$} & \multirow{2}{*}{$\begin{array}{c}\text { Upazila } \\
\text { Officials } \\
\text { Number }\end{array}$} & \multirow{2}{*}{$\begin{array}{c}\begin{array}{c}\text { Local } \\
\text { People }\end{array} \\
\text { Number }\end{array}$} & & \\
\hline & & & & & & & Number & Percentage \\
\hline $20-30$ & - & - & 2 & - & 5 & 20 & 27 & $16.9 \%$ \\
\hline $31-40$ & 2 & 1 & 4 & 3 & 15 & 23 & 48 & $30.0 \%$ \\
\hline $41-50$ & 4 & 2 & 6 & 5 & 17 & 4 & 38 & $23.8 \%$ \\
\hline $51-60$ & 1 & 3 & 3 & - & 3 & 26 & 36 & $22.5 \%$ \\
\hline $61+$ & 1 & 2 & 1 & - & - & 7 & 11 & $6.8 \%$ \\
\hline Total & 8 & 8 & 16 & 8 & 40 & 80 & 160 & $100.0 \%$ \\
\hline \multicolumn{9}{|l|}{ Education } \\
\hline Below SSC & - & - & 2 & - & - & 22 & 24 & $15.0 \%$ \\
\hline SSC & - & - & 3 & - & - & 17 & 20 & $12.5 \%$ \\
\hline $\mathrm{HSC}$ & 1 & 2 & 6 & - & - & 19 & 28 & $17.5 \%$ \\
\hline Graduate & 3 & 4 & 4 & - & 13 & 12 & 36 & $22.5 \%$ \\
\hline Post graduate & 4 & 2 & 1 & 8 & 27 & 10 & 52 & $32.5 \%$ \\
\hline Total & 8 & 8 & 16 & 8 & 40 & 80 & 160 & $100.0 \%$ \\
\hline \multicolumn{9}{|l|}{ Occupation } \\
\hline Service & - & - & - & 8 & 40 & 6 & 54 & $33.8 \%$ \\
\hline Business & 6 & 7 & 11 & - & - & 22 & 46 & $28.8 \%$ \\
\hline Teacher & - & 1 & 2 & - & - & 10 & 13 & $8.1 \%$ \\
\hline Agriculture & 2 & - & 2 & - & - & 3 & 7 & $4.4 \%$ \\
\hline Students & - & - & - & - & - & 11 & 11 & $6.9 \%$ \\
\hline Others & - & - & 1 & - & - & 28 & 29 & $18.1 \%$ \\
\hline Total & 8 & 8 & 16 & 8 & 40 & & 160 & $100.0 \%$ \\
\hline \multicolumn{9}{|l|}{ Gender } \\
\hline Male & 8 & 8 & 14 & 7 & 35 & 68 & 140 & $87.5 \%$ \\
\hline Female & - & - & 2 & 1 & 5 & 12 & 20 & $12.5 \%$ \\
\hline
\end{tabular}




\begin{tabular}{|l|l|l|l|l|l|l|l|l|}
\hline Total & 8 & 8 & 16 & 8 & 40 & 80 & 160 & $100.0 \%$ \\
\hline
\end{tabular}

Demographic variables of age, education, gender and occupation can be considered important values held by the role actors in politics and administration. Table 3.1 shows that, most of the local respondents belonged to the 30-50 age category. More particularly, 27 (16.9\%) of the respondents were aged 20-30, 48 (30\%), were aged 31-40, 38 (23.8\%) were aged group 41-50, and the remainder were aged 51-80. Education is one of the important factors that help a person acquire leadership roles in politics and administration. From the above demographic data of the respondents contain in the Table 3.1 shows that most of the respondents are educated. Among the respondents of the eight Upazilas 24 (15.0\%) are below SSC level while 36 (22.5\%) and 52 (32.5\%) respondents are hold the graduate and post-graduate degree respectively.

The findings of this study reveal an important occupational shift in the background of the respondents; formerly agriculture would have been the dominant occupation with some professions such as doctors and lawyers, but in the survey many respondents were involved in business and services (both government and private). Table 3.1 shows that among the respondents 54 (33.8\%) were in service jobs and 46 (28.8\%) in business. In considering gender category, 140 (87.5\%) were male and 20 (12.5\%) were female. In two Upazilsas the Women Vice-Chairmen could not be found during the data collection period, as they have no specific function in the current Upazila administration so they do not attend regularly. Meanwhile, there are few women officials of this Upazila.

\subsection{Levels of awareness amongst local people}

In this study, to identify the level of awareness about the roles and responsibilities of the public representatives, a number of questions were asked to the respondents of the local people of the eight Upazilas, for example: "Do you know the roles and functions of the Upazila chairman and UNO?" "Do you know what are the roles and functions of MPs?" as outlined below.

Figure 3.1 and 3.2: Awareness of Roles and Functions of MP, UNO \&Chairman of the Upazila Parishad
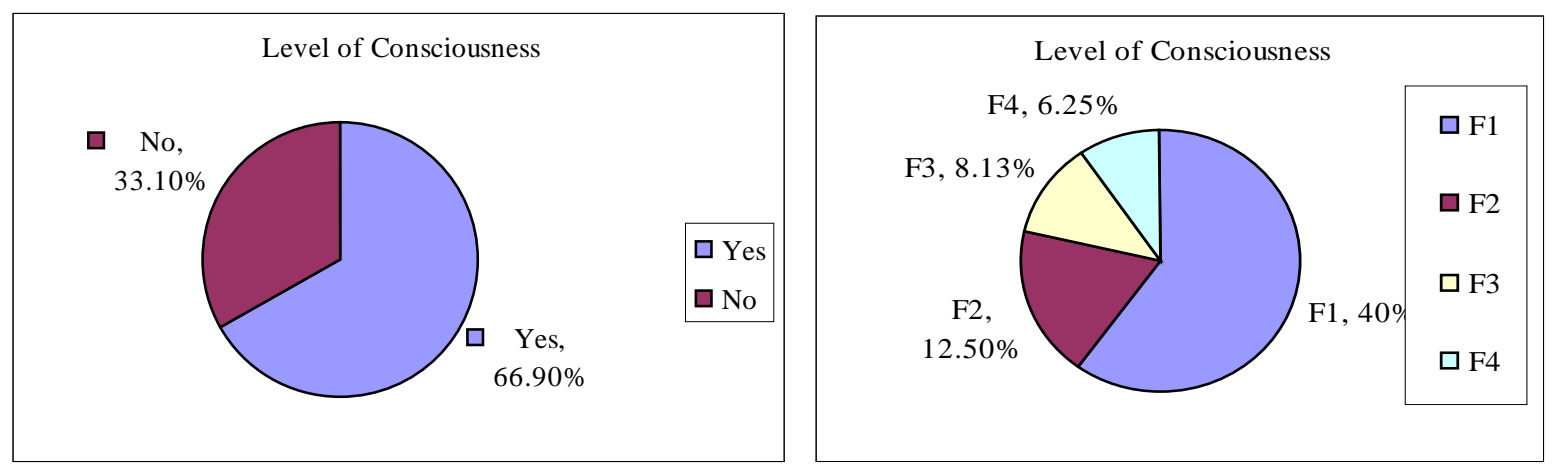
Figures 3.1 and 3.2 suggest that levels of awareness of the roles the Upazila Chairman and the UNO are not clear. Although when asked the question, "Do you know the roles and functions of the Upazila Chairman and UNO?" 107 (66.9\%) respondents answered "Yes", and 53 (33.1\%) said "No", but when asked to provide data on the duties of the Chairman and UNO, they were confused. Figure 3.2 shows that only $64(40.0 \%)$ of respondents were able identify only one duty, 20 (12.5\%) were able to identify two functions, 13 (8.1\%) were able to identify three duties, and only 10(6.3\%) were able to identify four duties and functions of elected representatives and bureaucrats in the Upazila Parishad.

\subsection{Grassroots view of the role of elected representatives}

Most people consider public representatives as local guardians who work with them, and with whom they can share all sorts of personal, social, religious and political thoughts and beliefs. To further probe this issue respondents were asked a number of questions: "Do you think that there should be any involvement of MPs in local government?" (Figure 3.5) "If yes, then why?" (Table 3.2) and "Who should have major roles in the local government?" (Figure 3.6).

Figure 3.5: Involvement of MPs?

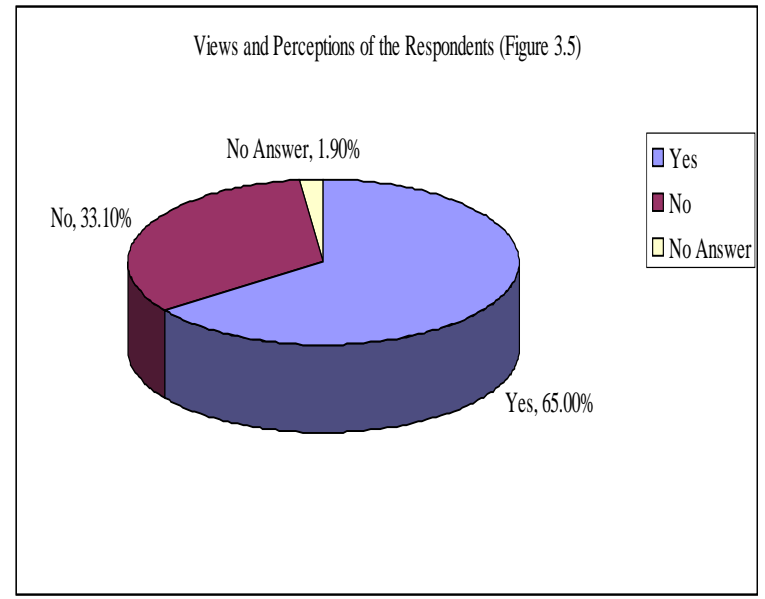

Figure 3.6: Who should perform major roles?

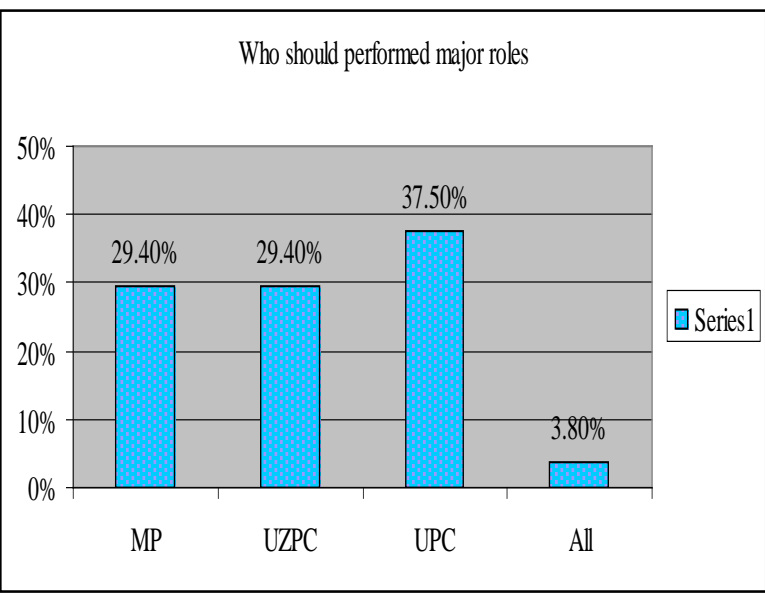

Figure 3.5 shows that most of the respondents think that the MPs should have a role in local government. Among the sample respondents 104 (65.0\%) provided the answer "Yes", 53 (33.1\%) provided the answer "No" and 3 (1.9\%) gave no reply. The data suggests that local citizens support the role of MPs in local government. The reasons provided by respondents are as follows.

Respondents were then asked, "Who should have major roles in local government?" and given the options of: 1=MP; 2=Upazila Parishad Chairman; 3=Union Parishad Chairman, and 4=All of Them. The data from Figure 3.6 demonstrates that 47 (29.4\%) respondents think that the MPs should have a major role in the local government, and the same portion of also think that Upazila Parishad Chairman should have the major role. On the other hand, 60 (37.5\%) respondents hold that Union 
Parishad Chairman should have a major role in local government and only 6(3.8\%) believe that all of them are equally responsible and should work together.

Table 3.2: Why should MPs have a role in local government? Respondents' Views

\begin{tabular}{|c|l|c|}
\hline SL No & Reasons provided by the respondents & Frequency \\
\hline 1 & He is an elected representative of the constituency & 23 \\
\hline 2 & He knows well about the people and the locale & 7 \\
\hline 3 & To represent the constituency to the central government & 7 \\
\hline 4 & To ensure democratic practice & 1 \\
\hline 5 & To oversight the development works & 22 \\
\hline 6 & To ensure public facilities and welfare & 7 \\
\hline 7 & MP's contribution is more than any other to the constituency & 2 \\
\hline 8 & To develop the constituency & 12 \\
\hline 9 & To help the local government & 3 \\
\hline 10 & To provide development plan & 104 \\
\hline
\end{tabular}

One interesting matter was that when asked the question, "Do you think that there should be any involvement of MPs in local government?" 104 (65.0\%) of respondents answered "Yes" (Figure 3.5), but when another question was asked, "Who should have major roles in local government?" then only 47 (29.4\%) respondents supported the same view (Figure 3.6). Ultimately, this suggests that the perceptions of the local citizens are confused in identifying the roles of public representatives in local government. The responses to the question, "What are your expectations of MPs?" are in Table 3.3.

Table 3.3: Expectations of the Respondents of MPs and Bureaucrats

\begin{tabular}{|c|l|}
\hline SL No & Types of Expectations \\
\hline 1 & Proper functioning of Upazila Parishad \\
\hline 2 & Development of the constituency \\
\hline 3 & Proper address/ solution of local problems \\
\hline 4 & Fulfillment of election manifesto \\
\hline 5 & Good governance \\
\hline 6 & Strengthening law and order situation \\
\hline 7 & Being close to the people \\
\hline 8 & Being careful / helpful to the local people \\
\hline 9 & Local infrastructure development \\
\hline 10 & Work based on people's desire \\
\hline 11 & Allocation of sufficient budget in health and education sectors \\
\hline
\end{tabular}




\subsection{Workings of the Upazila Parishad: conflict and cooperation}

Local government is based on community governance, and focused on citizen-centered local governance. It is the primary agent for the citizens and leader and gatekeeper for shared rule, is responsive and accountable to local voters. To identify the level of functioning and the degree of people's satisfaction, respondents were asked two questions 'what is the present condition of activities of your Upazila and are you satisfied with the existing Upazila system?’ Respondents' data are shown in the following table.

Table 3.4: Respondents' opinions on the functioning of Upazila Parishad

\begin{tabular}{|c|c|c|c|c|c|c|c|c|c|}
\hline \multirow{2}{*}{$\begin{array}{l}\text { Respondent } \\
\text { Category }\end{array}$} & \multicolumn{4}{|c|}{ Levels of functioning } & \multicolumn{4}{|c|}{ Degree of satisfaction } & \multirow[t]{2}{*}{ Total } \\
\hline & $\begin{array}{l}\text { Very } \\
\text { Good }\end{array}$ & Good & $\begin{array}{l}\text { Mod- } \\
\text { erate }\end{array}$ & $\begin{array}{l}\text { Not } \\
\text { Good }\end{array}$ & $\begin{array}{l}\text { Satis- } \\
\text { fied }\end{array}$ & $\begin{array}{c}\text { Part } \\
\text { Satis- } \\
\text { fied }\end{array}$ & $\begin{array}{c}\text { Not } \\
\text { Satis- } \\
\text { fied }\end{array}$ & $\begin{array}{c}\text { No } \\
\text { Reply }\end{array}$ & \\
\hline Upazila Chairman & 1 & 2 & 5 & - & 2 & 3 & 2 & 1 & 8 \\
\hline Vice-Chairman & - & 2 & 4 & 2 & - & 2 & 4 & 2 & 8 \\
\hline Member & 3 & 4 & 6 & 3 & 3 & 6 & 5 & 2 & 16 \\
\hline UNO & 3 & 4 & 1 & - & 5 & 2 & - & 1 & 8 \\
\hline Upazila Officials & 9 & 11 & 15 & 5 & 12 & 18 & - & 10 & 40 \\
\hline Ordinary People & 8 & 17 & 42 & 13 & 13 & 19 & 32 & 16 & 80 \\
\hline Total & 24 & 40 & 73 & 23 & 35 & 50 & 43 & 32 & 160 \\
\hline
\end{tabular}

Politicians and bureaucrats are an integral part of the governance and policy processes of the administration. The degree of success or failure in governing processes depends on the relation between politicians and bureaucrats. However, this relationship has not been without difficulties. Tension occurs when conflict arises between two actors in the context of policy formulation and implementation. In general, policies are chosen and implemented by both elected representatives (politicians) and non elected bureaucrats. So, the effective function of administration depends on the mode of interaction between the sets of actors - elected politicians and bureaucrats - and they both need to be accountable to people. In this respect, to understand the process of government, how it may be changing and how strategies for influencing policy are affected, we need to know about the relationship between politicians and bureaucrats (Aberbach et al 1981). The criteria that lead a society to allocate decision-making power between politicians or bureaucrats is a major question. The starting point is the premise that politicians are motivated by the goal of re-election goal, whereas bureaucrats are motivated by "career concerns". So, while politicians want to be re-elected, bureaucrats want to improve their professional prospects in the public or private sector which motivates them to perform well whatever tasks they receive (Wilson, 1989). As a result, conflict occurs in policy formulation and implementation process. 
To identify the conflict between local politicians and bureaucrats in the Upazila administration the respondents were asked the question, 'Do you think that there is a conflict between the MP, Chairman and the UNO? If yes then why and what are the types?' Overall, $67 \%$ of respondents thought that conflict existed, $8 \%$ held that there was no conflict, and 25\% made no comment. The respondents that were silent also assumed that the triangle of conflict existed in the Upazila, but for special reason they did not wanted to disclose their opinion. Why do conflicts arise and what are the grounds of this conflict? In this regards, the following types of conflicts have been identified on the basis of respondents' opinions.

Table 3.5: Ground of conflicts among MP, Chairman and UNO (Respondents opinion)

\begin{tabular}{|c|l|}
\hline SL No & Ground and types of conflict \\
\hline 1 & Interference to the other's jurisdiction \\
\hline 2 & Practice of power and benefits \\
\hline 3 & Budget allocation and benefits of stakeholder \\
\hline 4 & Priority selection in development activities eg: GR, TR, VGD, VGF, KABIKHA, KABITA etc \\
\hline 5 & Sense of ownership of the Upazila \\
\hline 6 & In controlling of Upazila officers (ACR) \\
\hline 7 & Duel rule or administration \\
\hline 8 & Autocratic attitude of UNO and chairman \\
\hline 9 & Grouping among the officers of Upazila administration \\
\hline 10 & In the question of corruption and accountability \\
\hline 11 & Superiority conflict \\
\hline
\end{tabular}

\subsection{Conclusion}

This study reveals that a strong local government system (where strong coherence is present among various actors) can ensure good governance through transparency, accountability, effective participation and equal opportunities for all. Most importantly, this system can ensure development at the grassroots level, but local citizens lack awareness of this issue. By capitalizing on this gap, central government and politicians establish their control over local government and they use the bureaucracy for their purpose. The advisory role of MPs in local government is to some extent forgotten, and interference by MPs in local government affairs, particularly in development activities, has weakened the independence of local government. MPs often dictate the development activities to be undertaken without consulting with the local elected representatives or assessing actual need. Under the 2008 legislation, at least theoretically, the Upazila Parishad have lost the characteristics of local government bodies, since MPs are authorized to advise on the activities of these bodies. The current law has already given rise to a row between Upazila Chairmen and MPs, and it is likely that this discord will further destabilize the political arena of the country. Ambiguity in role definition and conflicting Interests between bureaucrats and elected representatives render the local government especially Upazila Parishad dysfunctional. 
A very interesting and unfortunate reality is that local citizens appear to support the advisory role of MPs in local government. They think that as a public representrative of the constituency MPs should have a role in local government. So, it is very difficult to confine the role of MPs in Bangladesh to Parliament, though it is generally recognized that as a member of the legislative assembly the first and foremost duty and responsibility of an MP is to make laws and policies. Consequently, the data in this study reveals that the levels of awareness of local citizens is low and only $30 \%$ of respondents are concerned about the roles and functions of the Upazila Parishad. The data from Figure 3.4 suggests that although local citizens think that they are knowledgeable about the roles and functions of MPs, more than $60 \%$ of the sample are not concerned about the roles and functions of the MPs. Moreover, consciousness varies on the basis of demographic variables such as age, educational status, occupational status and gender. Among the respondents 104 (65.0\%) think that MPs should have a role in the local government, but when asked the question in a different way only 47 (29.4\%) of respondents supported the same view. This could lead to a much stronger conclusion - that MPs are playing a role in local government that is not clearly defined or accountable, and until locally-elected representatives regain control over development activities, local government will not be fully accountable to its electorate.

\section{References}

Aberbach, J., Putnam, R. and Rockman, B, (1981). Bureaucrats and Politicians in Western Democracies, Cambridge: Mass, Harvard University Press

Arlblaster, A. (2002). “Democracy”, Buckingham: Open University Press

Ahmed, N. (2009). Bureaucracy and Local Politics in Bangladesh, Dhaka: AHD Publishing House

Ahmed Nizam, Ahmed Tofail and Faizullah Mohammad, (2011). Working of Upazila Parishad in Bangladesh: A Study of Twelve Upazilas, Dhaka: UNDP

CLGF, (2012) The local government system in Bangladesh: Country profile, http://www.clgf.org.uk/userfiles/1/files/Bangladesh\%20local\%20government\%20profile\%20201112.pdf, accessed October 2012

Davis, K. (1948). Human Society, New York: the Macmillan Press

GPRB (1972) The Constitution of Bangladesh, GPRB (Government of the People's Republic of Bangladesh), http://bdlaws.minlaw.gov.bd/

GPRB (2001) The Rules of Business, 2001, GPRB (Government of the People's Republic of Bangladesh), http://bdlaws.minlaw.gov.bd/

GPRB (1982) The Upazila Ordinance of 1982, GPRB (Government of the People's Republic of Bangladesh)

GPRB (1998) The Upazila Act of 1998, GPRB (Government of the People's Republic of Bangladesh), http://bdlaws.minlaw.gov.bd/

GPRB (2009) The Upazila Parisad (Reintroduction of the Repealed Act Amendment) Act 2009, GPRB (Government of the People's Republic of Bangladesh), http://bdlaws.minlaw.gov.bd/

GPRB (2009) The Upazila Act, 2009, GPRB (Government of the People's Republic of Bangladesh), http://bdlaws.minlaw.gov.bd/

Khan, M.M, (2009), Decentralization in Bangladesh, Dhaka: AHD Publishing House 
Lilleker, D. and Jackson, N. (2009), “Interacting and Representing: can Web 2.0 enhance the roles of an MP" ECPR workshop "Parliaments, Parties and Politicians in Cyberspace", Lisbon, April 2009

Norton, P. and Wood, D. (1990). Constituency Service by Members of Parliament: does it contribute to a personal vote Parliamentary Affairs, Oxford University Press, Cambridge, pp196-208

Norton, P., (1994), “The Growth of the Constituency Role of the MP”, Parliamentary Affairs, volume 47(4) pp 705-20

Pickles, D., (1971) Democracy, London: B.T Batsford Ltd

Rahman, N. (2009), The Road to Local Government, however Unsatisfactory, Star Weekend Magazine, Volume 8 (59) February 27

Rahman, M. S., (2010). 'Politicians and Bureaucrats in Upazila Administration: A Study on ConflictRelationships' in the Dynamics of Public Administration, An Indian Journal, Vol. 27(2), July-December 2010

Rush, M. (2001) “The role of the Member of Parliament since 1968: From Gentlemen to Players”, Oxford University Press, London

Siddiqui, K. (ed), (2005). Local Government in Bangladesh, Dhaka: University Press Limited

Stilborn, Jack, (2012). The Roles of the Members of Parliament in Canada: Are They Changing? Canada: Political and Social Affairs Division

Wilson, J.Q. (1989). Bureaucracy Basic Books, New York

http://www.bangladesh2day.com/newsfinance/2009/January/22/Nation-goes-to-Upazila-pollsof-hope-today.php http://www.thedailystar.net/magazine/2009/02/04/cover.htm 


\section{Appendix}

Questionnaire

\section{Working of Upazila Parishad in Bangladesh: exploring Roles and Functions of Elected Representatives and Bureaucrats}

Name of the Upazila.

Sample No.......

(NB: The data of this study will be used for only academic purposes)

Name.

Designation. Age.

Education Occupation

Gender. Income(Yearly).

1. What is the condition of the activities of your Upazila?
A. Very Good
B. Good
C. Moderate
D. Not So Good

2. Are you satisfied in the existing Upazila system?
A. Satisfied
B. Partial Satisfied
C. Not Satisfied

3. Do you know what are the roles and functiond of elected representatives ( MP and Chairman) and Local official Bureaucrats( UNO)?
A. Yes
B. No
C. No Response

4. If answer is yes then would you like to tell some of the roles and functions of MP, Chairman and UNO?

\begin{tabular}{|l|l|l|}
\hline \multicolumn{1}{|c|}{ MP } & \multicolumn{1}{|c|}{ Upazila Chairman } & \multicolumn{1}{c|}{ UNO } \\
\hline 1. & 1 & 1 \\
\hline 2. & 2 & 2 \\
\hline 3. & 3 & 3 \\
\hline 4. & 4 & 4 \\
\hline
\end{tabular}

5. Who leads the major policy decisions in this Upazila?
A. Chairman
B. UNO
C. MP
D. By Consensus

6. How do you evaluate your role?
A. Delegate
B. Trustee
C. Political
D. Legal

7. How is the working relation between Upazila chairman and UNO?
A. Very good
B. Good
C. Moderate
D. Bad

8. Who should have major role in the local government?
A. MP
B. UPZC
C. UPC
D. All of them

9. What do you expect from elected representatives?

10. What is the nature of conflict and why conflict occurs in the Upazila? 